Volume 3 • Nomor 1 • Oktober 2019

Pege (Hal.) : $79-87$

(C) Universitas Pamulang

JL.Surya Kencana No.1 Pamulang, Tangerang Selatan - Banten

website. :

Telp. (021) 7412566, Fax (021) 7412491

http://www.openjournal.unpam.ac.id/index.php/JPK Email : jurnalmarketing.unpam@gmail.com

\title{
Pengaruh Strategi Pemasaran Dan Pelayanan Umum Terhadap Kepuasan Nasabah Pada PT. Bank Danamon Tbk. Kantor Cabang Tangerang Selatan
}

\author{
Syahnego \\ Universitas Pamulang, : syahnego@yahoo.com
}

\begin{abstract}
Abstrak. Tujuan dari penelitian ini untuk mengetahui pengaruh strategi pemasaran terhadap kepuasan nasabah pada PT. Bank Danamon Tbk kantor cabang Tangerang Selatan, untuk mengetahui pengaruh pelayanan umum terhadap kepuasan nasabah pada PT. Bank Danamon Tbk kantor Cabang Tangerang Selatan, untuk mengetahui pengaruh strategi pemasaran dan pelayanan umum terhadap kepuasan nasabah pada PT. Bank Danamon Tbk. kantor cabang Tangerang Seatan. Penelitian ini bersifat observasional analitik dengan metode kuantitatif, Data dikumpulkan melalui penyebaran kuisioner langsung kepada responden sebanyak 105 responden yang diambil menggunakan rumus Slovin dengan populasi sebanyak 1.800.000 nasabah PT. Bank Danamon Tbk. kantor cabang Tangerang Selatan.

Hasil penelitian ini menunjukkan bahwa: Terdapat pengaruh strategi pemasaran terhadap kepuasan nasabah, dilihat dari nilai thitung $>$ ttabel yaitu $5.147>1.982$, pengaruh pelayanan umum terhadap kepuasan nasabah, terbukti nilai thitung $>$ Ttabel yaitu $6.091>1.982$. Pengaruh strategi pemasaran dan pelayanan umum terhadap kepuasan nasabah, terbukti nilai Fhitung > Ftabel yaitu $449.727>$ 2.69, dengan tingkat signifikan 0,000 <0,05 sehingga dapat dikatakan maka Strategi Pemasaran (X1) dan Pelayanan Umum (X2) secara bersama-sama berpengaruh terhadap Kepuasan Nasabah (Y). Sedangkan nilai Adjusted R Square sebesar 0.896.
\end{abstract}

\section{Keywords: Strategi Pemasaran; Pelayanan Umum; Kepuasan Nasabah}

Abstract. The purpose of this study are to determine the effect of marketing strategies on customer satisfaction at PT. Bank Danamon Tbk South Tangerang Branch Office. To determine the effect of public services on customer satisfaction at PT. Bank Danamon Tbk South Tangerang Branch Office and to determine the effect of marketing strategies and general services on customer satisfaction at PT. Bank Danamon Tbk South Tangerang Branch Office.

This research was an observational analytic study with quantitative research methods, Data was collected through distribution of questionnaires to 105 respondents. The population in this study was 1,800,000 customers of PT. Bank Danamon Tbk South Tangerang Branch Office. The sampling technique to be used is the Slovin Formulaa.

The results of this study indicate that: The effect of marketing strategy on customer satisfaction, proved the tcount for Marketing Strategy (X1) amounted to 5,147, while the value of the table for $n=105$ was 1,982. So 5,147> 1,982, The effect of public services on customer satisfaction, proved the value of tcount for Public Services (X2) amounted to 6,091, while the value of the table for $n=105$ was 1,982. So 6,091> 1,982. The effect of marketing strategies and general services on customer satisfaction, proved the Fcount value of 449,727 while the Ftable $(\square 0.05)$ for $n=105$ of 2.69. So Fcount $>$ from Ftable $(\square 0.05)$ or $449,727>2.69$, with a significant level of 0,000 because $0,000<0.05$ so that it can be said that the Marketing Strategy (X1) and Public Service (X2) together affect the Customer Satisfaction (Y). While the Adjusted $R$ Square value of 0.896 .

Key words: Marketing Strategy; General Services; Customer Satisfaction 


\section{A. PENDAHULUAN}

Pelayanan umum dapat dikatakan faktor yang sangat penting dalam meningkatkan keberhasilan usaha perusahaan. Tidak hanya mengenai bisnis perbankan saja tetapi mencakup semua perusahaan. Tetapi perusahaan juga harus menyadari pentingnya pengetahuan berwawasan pelanggan dan mementingkan pelanggan.

Untuk memenuhi kebutuhan nasabah dan membuat pelanggan merasa puas bukanlah suatu hal yang mudah, karena mengingat akan tingginya tuntutan nasabah pada suatu produk atau jasa. Pada saat nasabah membeli suatu produk atau jasa tertentu, nasabah mengharapkan pelayanan maksimal yang menyertai produk dan jasa tersebut. Di samping itu produk yang ditawarkan oleh perusahaan perbankan itu sendiri, pelayanan baik yang menyertai suatu produk tertentu akan memberikan nilai tambah di mata nasabah.

Jika dilihat dari global persaingan bank-bank yang kedudukannya tinggi di Indonesia pada beberapa tahun ini, persaingan perbankan terlihat memang begitu sengit. Rasio peningkatan kepemilikan dan pihak ketiga atau pihak-pihak yang bekerjasama yang dimiliki maka semakin baik hubungan bank tersebut dengan para nasabah dan juga dapat mencerminkan tingkat hubungan bank-bank tersebut dengan para nasabahnya.

Perusahaan dapat meningkatkan komoditas penjualannya melalui pemenuhan pelayanan umum. Jika kinerja pelayanan umum yang dihasilkan baik dan jumlah pangsa pasar yang dimiliki besar, maka profitabilitasnya tinggi dan akan terjamin. Demikian kualitas layanan produk/jasa dan profitabilitas sangatlah berhubungan erat. Perusahaan yang dapat memberikan pelayanan yang baik maka perusahaan tersebut dapat mengalahkan pesaingnya yang jika memberikan pelayanan yang kurang baik.

Perumusan Masalah: 1. Bagaimana pengaruh strategi pemasaran terhadap kepuasan nasabah pada PT. Bank Danamon Tbk Kantor Cabang Tangerang Selatan? 2. Bagaimana pengaruh pelayanan umum terhadap kepuasan nasabah pada PT. Bank Danamon Tbk Kantor Cabang Tangerang Selatan? 3. Bagaimana pengaruh strategi pemasaran dan pelayanan umum terhadap kepuasan nasabah pada PT. Bank Danamon Tbk Kantor Cabang Tangerang Selatan?

Tujuan Penelitian: 1. Untuk mengetahui pengaruh strategi pemasaran terhadap kepuasan nasabah pada PT. Bank Danamon Tbk Kantor Cabang Tangerang Selatan. 2. Untuk mengetahui pengaruh pelayanan umum terhadap kepuasan nasabah pada PT. Bank Danamon Tbk Kantor Cabang Tangerang Selatan. 3. Untuk mengetahui pengaruh strategi pemasaran dan pelayanan umum terhadap kepuasan nasabah pada PT. Bank Danamon Tbk Kantor Cabang Tangerang Selatan.

\section{B. KAJIAN LITERATUR}

Strategi Pemasaran

Siagian dikutip oleh Irma (2016:20) mengemukakan pengertian strategi pemasaran "mengambil keputusan dan tindakan yang dibuat oleh manajemen puncak dan diimplementasikan untuk keseluruhan pihak dalam rencana perusahaan mencapai suatu tujuan".

Kemudian pendapat Kotler \& Armstrong (2012:72) strategi pemasaran yaitu : logika pemasaran dimana unit perusahaan berharap bisa menciptakan nilai yang baik bagi pelanggan dan dapat kesempatan mencapai hubungan yang menguntungkan dengan para pelanggan.

Pelayanan Umum 
Pelayanan menurut Albercht dan Lovelock (dalam Sedarmayanti, 2010:243) yaitu "suatu pendekatan organisasi yang menjadi kualitas pelayanan dan diterima oleh pengguna jasa sebagai kekuatan penggerak utama dalam pengoperasian bisnis".

Kepuasan Nasabah

Menurut Lovelock dan Wirtz (2011:74) "kepuasan adalah suatu sikap yang diputuskan berdasarkan pengalaman yang didapatkan". Sedangkan pengertian kepuasan nasabah itu sendiri, menurut pendapat Nasution (dalam Majid, 2011:50), kepuasan nasabah secara sederhana yaitu, suatu keadaan dimana keinginan, kebutuhan, dan harapan pelanggan dapat terpenuhi melalui produk/jasa yang digunakan. Jadi, tingkat kepuasan adalah dimana fungsi dari perbedaan apabila kinerja di bawah harapan/keinginan, nasabah akan kecewa. Jika kinerja melebihi harapan yang diingikan nasabah maka nasabah akan merasa puas.

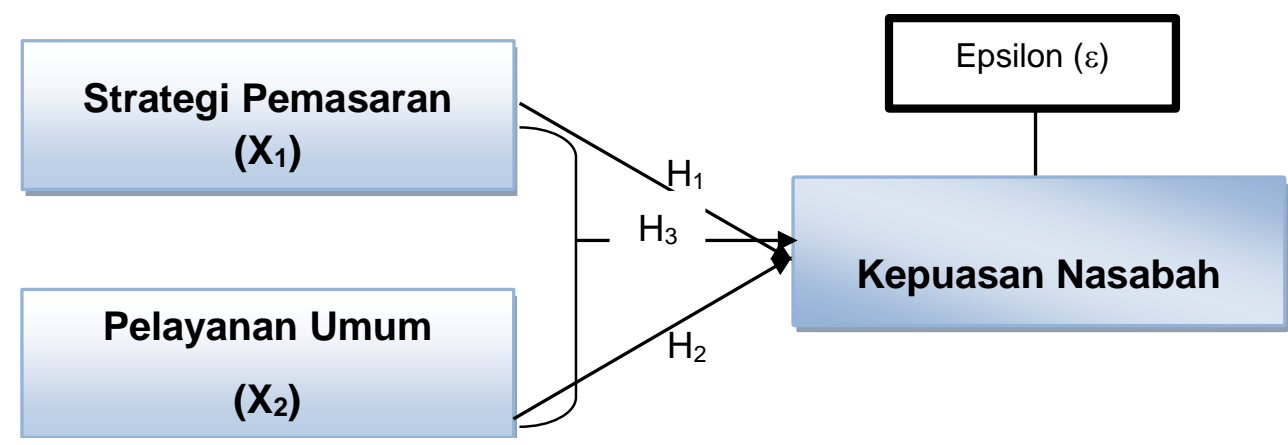

Keterangan:

Gambar 1 : Kerangka Konseptual

$\mathrm{X} 1=$ Variabel bebas I (Strategi Pemasaran)

$\mathrm{X} 2=$ Variabel bebas II (Pelayanan Umum)

$Y \quad=$ Variabel terikat (Kepuasan Nasabah)

$\varepsilon \quad=$ Variabel-variabel lainnya yang mempengaruhi Kepuasan Nasabah di luar X1 dan X2 yang tidak diteliti

\section{METODOLOGI PENELITIAN}

Penelitian ini merupakan penelitian observasional analitik, yaitu "peneliti melakukan pengamatan langsung kepada responden dengan melakukan penyebaran kuisioner untuk dianalisis menggunakan metode penelitian kuantitatif'. Penelitian kuantitatif mengambil jarak antara peneliti dengan objek yang diteliti. Kemudian, penelitian kuantitatif menggunakan instrumen-instrumen formal, standar dan bersifat mengukur (Sukmadinata, 2006:95).

Menurut peneliti Umar (2011:77), mengartikan "populasi sebagai wilayah generalisasi yang terdiri atas objek atau subjek yang mempunyai karakteristik tertentu dan mempunyai kesempatan yang sama untuk dipilih menjadi anggota sampel". Maka yang menjadi populasi pada penelitian ini adalah 1.800.000 nasabah PT. Bank Danamon Tbk Kantor Cabang Tangerang Selatan.

Teknik sampling yang akan digunakan adalah Rumus Slovin. Dalam penelitian ini penulis mempersempit populasi sebagai jumlah seluruh nasabah PT. Bank Danamon Tbk Kantor Cabang Tangerang Selatan sebanyak 1.800.000 nasabah dengan perhitungan ukuran sampel yang dilakukan peneliti dengan menggunakan teknik Rumus Slovin, yang dikemukakan oleh Sugiyono (2011:87): 
ISSN NO. (PRINI) 2598-0823, (ONLINE) 2598-2893

$$
\begin{aligned}
& \mathrm{n}=\frac{\mathrm{N}}{1+\mathrm{N} \mathrm{e2}}=\frac{1.800 .000}{1+1.800 .000(0.1) 2}=\frac{1.800 .000}{1+1.800 .000(0.01)} \\
& =\quad \frac{1.800 .000}{18,001} \\
& =99,99 \text { dibulatkan menjadi 105 responden }
\end{aligned}
$$

Teknik analisis kuantitatif dengan menggunakan uji statistik antara lain: Uji Instrumen, Uji Klasik. Uji Regresi Linier Berganda, Uji Koefisien Determinasi. input data, statistik digunakan program SPSS (Statistical Product and Service Solutions) versi 20.

\section{HASIL DAN PEMBAHASAN}

Uji Validitas

Tabel 1

\begin{tabular}{|c|c|c|c|}
\hline $\begin{array}{l}\text { No. Butir } \\
\text { Instrumen }\end{array}$ & Nilai $\mathbf{r}_{\text {hitung }}$ & $\begin{array}{c}\text { Nilai } r_{\text {tabel }} \\
n=105\end{array}$ & Keterangan \\
\hline 1 & 0.817 & 0.190 & Valid \\
\hline 2 & 0.645 & 0.190 & Valid \\
\hline 3 & 0.703 & 0.190 & Valid \\
\hline 4 & 0.451 & 0.190 & Valid \\
\hline 5 & 0.792 & 0.190 & Valid \\
\hline 6 & 0.703 & 0.190 & Valid \\
\hline 7 & 0.598 & 0.190 & Valid \\
\hline 8 & 0.812 & 0.190 & Valid \\
\hline 9 & 0.684 & 0.190 & Valid \\
\hline 10 & 0.610 & 0.190 & Valid \\
\hline 11 & 0.653 & 0.190 & Valid \\
\hline 12 & 0.655 & 0.190 & Valid \\
\hline
\end{tabular}

Hasil Uji Validitas Variabel Strategi Pemasaran $\left(\mathrm{X}_{1}\right)$

\begin{tabular}{|c|c|c|c|}
\hline $\begin{array}{c}\text { No. Butir } \\
\text { Instrumen }\end{array}$ & Nilai $\boldsymbol{r}_{\text {hitung }}$ & $\begin{array}{c}\text { Nilai rtabel } \\
\mathbf{n = 1 0 5}\end{array}$ & Keterangan \\
\hline 1 & 0.740 & 0.190 & Valid \\
2 & 0.682 & 0.190 & Valid \\
3 & 0.787 & 0.190 & Valid \\
4 & 0.591 & 0.190 & Valid \\
5 & 0.493 & 0.190 & Valid \\
6 & 0.719 & 0.190 & Valid \\
7 & 0.572 & 0.190 & Valid \\
8 & 0.782 & 0.190 & Valid \\
9 & 0.673 & 0.190 & Valid \\
10 & 0.575 & 0.190 & Valid \\
11 & 0.527 & 0.190 & Valid \\
12 & 0.740 & 0.190 & Valid \\
\hline \multicolumn{2}{|c}{ Sumber: Hasil Olahan Data (SPSS 20), 2019 } \\
\hline
\end{tabular}

Tabel 2

Hasil Uji Validitas Variabel Pelayanan Umum $\left(X_{2}\right)$

Sumber: Hasil Olahan Data (SPSS 20), 2019 
ISSN NO. (PRINT) 2598-0823, (ONLINE) 2598-2893

Tabel 3

Hasil Uji Validitas Variabel Kepuasan Nasabah ( $Y$ )

\begin{tabular}{|c|c|c|c|}
\hline $\begin{array}{c}\text { No. Butir } \\
\text { Instrumen }\end{array}$ & Nilai $\mathbf{r}_{\text {hitung }}$ & $\begin{array}{c}\text { Nilai } \mathbf{r}_{\text {tabel }} \\
\mathbf{n}=\mathbf{1 0 5}\end{array}$ & Keterangan \\
\hline 1 & 0.790 & 0.190 & Valid \\
2 & 0.678 & 0.190 & Valid \\
3 & 0.751 & 0.190 & Valid \\
4 & 0.568 & 0.190 & Valid \\
5 & 0.349 & 0.190 & Valid \\
6 & 0.709 & 0.190 & Valid \\
7 & 0.601 & 0.190 & Valid \\
8 & 0.814 & 0.190 & Valid \\
9 & 0.649 & 0.190 & Valid \\
10 & 0.629 & 0.190 & Valid \\
11 & 0.643 & 0.190 & Valid \\
12 & 0.701 & 0.190 & Valid \\
\hline
\end{tabular}

Sumber: Hasil Olahan Data (SPSS 20), 2019

Bersumber data tabel 1, 2 dan 3 di atas, dilihat bahwa setiap butir instrumen dari variabel $\mathrm{X} 1, \mathrm{X} 2$ dan $\mathrm{Y}$ seluruh instrument dikatakan valid, karena nilai rhitung lebih besar dari pada nilai rtabel yang ada untuk $n=105$ yaitu 0.190

Uji Reliabilitas

Tabel 4

Hasil Uji Reliabilitas Variabel Strategi Pemasaran $\left(X_{1}\right)$ Reliability Statistics

\begin{tabular}{|c|c|}
\hline $\begin{array}{c}\text { Cronbach's } \\
\text { Alpha }\end{array}$ & $\begin{array}{c}\text { N of } \\
\text { Items }\end{array}$ \\
\hline 881 & 12 \\
\hline
\end{tabular}

Sumber: Hasil Olahan Data (SPSS 20), 2019

Tabel 5

Hasil Uji Reliabilitas Variabel Pelayanan Umum $\left(\mathrm{X}_{2}\right)$ Reliability Statistics

\begin{tabular}{|r|r|}
\hline $\begin{array}{c}\text { Cronbach's } \\
\text { Alpha }\end{array}$ & $\begin{array}{c}\text { N of } \\
\text { Items }\end{array}$ \\
\hline 890 & 12 \\
\hline
\end{tabular}

Sumber: Hasil Olahan Data (SPSS 20), 2019

Tabel 6

Hasil Uji Reliabilitas Variabel Kepuasan Nasabah (Y) Reliability Statistics

\begin{tabular}{|r|r|}
\hline $\begin{array}{c}\text { Cronbach's } \\
\text { Alpha }\end{array}$ & $\begin{array}{c}\text { N of } \\
\text { Items }\end{array}$ \\
\hline 883 & 12 \\
\hline
\end{tabular}

Sumber: Hasil Olahan Data (SPSS 20), 2019 
Berdasarkan tabel di atas, untuk uji reliabilitas $\mathrm{X} 1, \mathrm{X} 2$ dan $\mathrm{Y}$ diperoleh nilai Alpha hitung lebih besar dari Alpha kritis $(0.883>0.600)$ semua pernyataan reliabel dan dapat digunakan sebagai variabel penelitian.

Uji Normalitas Data

Tabel 7

Hasil Uji Normalitas Data One-Sample Kolmogorov-Smirnov Test

\begin{tabular}{|ll|r|r|r|}
\hline & $\begin{array}{r}\text { Strategi } \\
\text { Pemasaran } \\
\left(\mathrm{X}_{1}\right)\end{array}$ & $\begin{array}{c}\text { Pelayanan } \\
\text { Umum } \\
\left(\mathrm{X}_{2}\right)\end{array}$ & $\begin{array}{c}\text { Kepuasan } \\
\text { Nasabah } \\
(\mathrm{Y})\end{array}$ \\
\hline $\mathrm{N}$ & Mean & 105 & 105 & 105 \\
Normal Parameters & Std. & 49.5429 & 48.9143 & 49.1238 \\
& Deviation & 6.56481 & 7.10920 & 6.73495 \\
Most Extreme & Absolute & .093 & .114 & .118 \\
Differences & Positive & .077 & .083 & .076 \\
Kolmogorov-Smirnov Z & Negative & -.093 & -.114 & -118 \\
Asymp. Sig. (2-tailed) & .949 & 1.172 & 1.204 \\
\hline
\end{tabular}

a. Test distribution is Normal

b. Calculated from data.

Sumber: Hasil Olahan Data (SPSS 20), 2019

Berdasarkan tabel 1.7 di atas, nilai signifikansi (2-tailed) variabel Strategi Pemasaran (X1) sebesar 0.329, variabel Pelayanan Umum (X2) sebesar 0.128 , sedangkan untuk variabel Kepuasan Nasabah (Y) sebesar 0.110. Ketiga nilai signifikansi (2-tailed) alat ukur tersebut berada di atas 0.05 sehingga data dikatakan berdistribusi normal. Sedangkan nilai Kolmogorov-Smirnov variabel Strategi Pemasaran (X1) sebesar 0.949, variabel Pelayanan Umum (X2) sebesar 1.172, sedangkan untuk variabel Kepuasan Nasabah (Y) sebesar 1.204, berarti data residual terdistribusi normal.

Untuk uji normalitas, penulis juga menggunakan grafik Normal P-Plot. Tabel tersebut dapat dilihat di bawah ini:

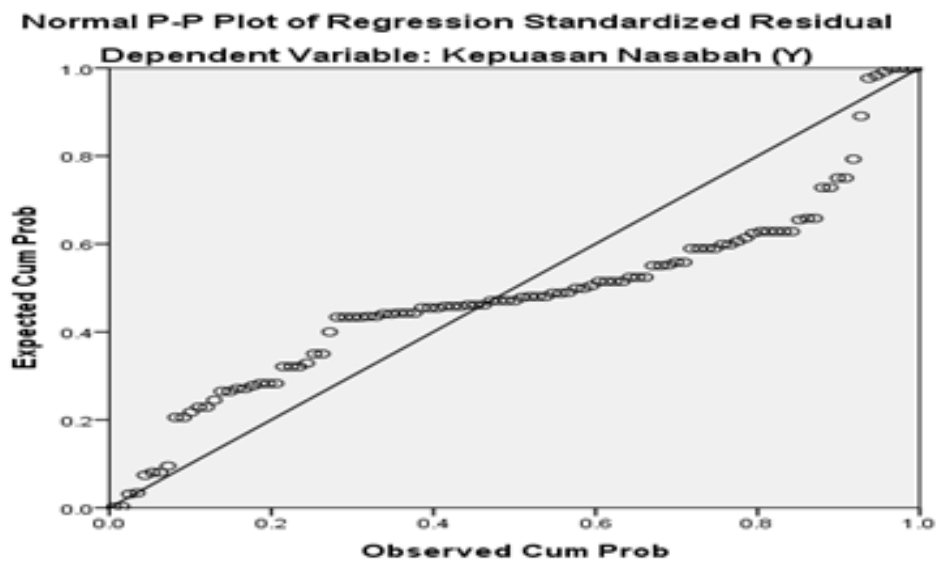

Sumber: Hasil Olahan Data (SPSS 20), 2019

Gambar 2 
Berasaskan pada gambar di atas dapat disesuaikan maka data dalam penelitian ini melaksanakan syarat normal probability plot sehingga model regresi dalam penelitian memenuhi dugaan normalitas yaitu berditribusi normal. Maknanya pada data penelitian ini berasal dari populasi yang berdistribusi normal.

Analisis Regresi Linier Berganda

Tabel 8. Hasil Uji Regresi Linier Berganda

\begin{tabular}{|c|c|c|c|c|c|c|}
\hline \multirow{3}{*}{\multicolumn{2}{|c|}{ Model }} & \multirow{2}{*}{\multicolumn{2}{|c|}{$\begin{array}{c}\text { Unstandardized } \\
\text { Coefficients }\end{array}$}} & \multirow{3}{*}{\begin{tabular}{|c|}
$\begin{array}{c}\text { Standardized } \\
\text { Coefficients }\end{array}$ \\
Beta
\end{tabular}} & \multirow{3}{*}{$\mathrm{t}$} & \multirow{3}{*}{ Sig. } \\
\hline & & & & & & \\
\hline & & $\mathrm{B}$ & $\begin{array}{l}\text { Std. } \\
\text { Error }\end{array}$ & & & \\
\hline & (Constant) & 2.439 & 1.622 & & 1.504 & .136 \\
\hline & Strategi Pemasaran $\left(X_{1}\right)$ & .453 & .088 & .442 & 5.147 & .000 \\
\hline & Pelayanan Umum $\left(X_{2}\right)$ & .495 & 081 & 523 & 6.091 & .000 \\
\hline
\end{tabular}

Berdasarkan hasil output SPSS tabel 1.8, hingga dapat diidentifikasikan bahwa persamaan regresi yaitu sebagai berikut penjelasannya:

$\mathrm{Y}=2.439+0.453 \mathrm{X} 1+0.495 \mathrm{X} 2$

Pengujian Hipotesis Uji t

Pengaruh Strategi Pemasaran (X1) terhadap Kepuasan Nasabah (Y)

Hasil uji pada tabel 1.8 (coefficients) di atas, didapat nilai thitung untuk Strategi Pemasaran (X1) sebesar 5.147, sedangkan nilai ttabel untuk $n=105$ sebesar 1.982 . Jadi $5.147>1.982$ maka $\mathrm{HO}$ ditolak dan Ha diterima sehingga dapat dinyatakan maka Strategi Pemasaran (X1) berpengaruh terhadap Kepuasan Nasabah (Y) pada PT. Bank Danamon Tbk Kantor Cabang Tangerang Selatan.

Pengaruh Pelayanan Umum (X2) terhadap Kepuasan Nasabah (Y)

Hasil uji pada tabel 1.8 (coefficients) di atas, didapat nilai thitung untuk Pelayanan Umum (X2) sebesar 6.091, sedangkan nilai ttabel untuk $n=105$ sebesar 1.982 . Jadi $6.091>1.982$ maka $\mathrm{HO}$ ditolak dan Ha diterima sehingga dapat dinyatakan maka Pelayanan Umum (X2) berpengaruh terhadap Kepuasan Nasabah (Y) pada PT. Bank Danamon Tbk Kantor Cabang Tangerang Selatan.

Pengujian Hipotesis Uji $f$

Tabel 9. Hasil Uji $f$

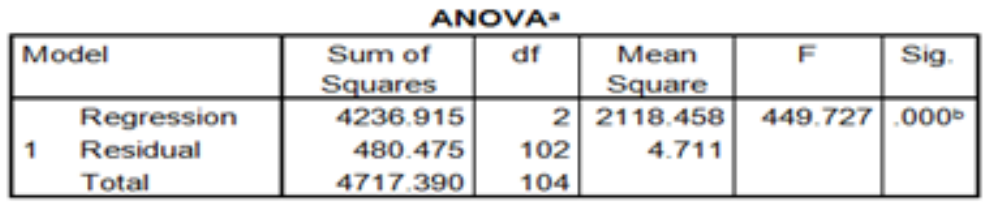

a. Dependent Variable: Kepuasan Nasabah $(Y)$

b. Predictors: (Constant), Pelayanan Umum $\left(X_{2}\right)$, Strategi

Pemasaran $\left(X_{1}\right)$ 
Berdasarkan hasil analisis pada tabel 1.9 di atas yakni uji ANOVA diperoleh nilai Fhitung sebesar 449.727 sedangkan Ftabel $(\square 0,05)$ untuk $n=105$ sebesar 2.69. Jadi Fhitung $>$ dari Ftabel $(\square 0,05)$ atau $449.727>2.69$, dengan tingkat signifikan sebesar 0,000 karena 0,000 $<0,05$ sehingga dapat dikatakan maka Strategi Pemasaran (X1) dan Pelayanan Umum (X2) secara bersama-sama berpengaruh terhadap Kepuasan Nasabah (Y).

Koefisien Determinasi (KD)

Tabel 10 Hasil Uji Koefisien Determinasi

\begin{tabular}{|c|c|c|c|c|}
\hline Model & $\mathrm{R}$ & $\begin{array}{l}\text { R } \\
\text { Square }\end{array}$ & $\begin{array}{l}\text { Adjusted R } \\
\text { Square }\end{array}$ & $\begin{array}{c}\text { Std. Error of } \\
\text { the } \\
\text { Estimate }\end{array}$ \\
\hline 1 & $.948^{\circ}$ & 898 & 896 & 2.17038 \\
\hline \multicolumn{5}{|c|}{$\begin{array}{l}\text { a. Predictors: (Constant), Pelayanan Umum }\left(X_{2}\right) \text {, } \\
\text { Strategi Pemasaran }\left(X_{1}\right)\end{array}$} \\
\hline \multicolumn{5}{|c|}{$\begin{array}{r}\text { b. Dependent Variable: Kepuasan Nasabah (Y) } \\
\text { Hasil Olahan Data (SPSS 20), } 2019\end{array}$} \\
\hline
\end{tabular}

Berdasarkan tabel 1.10 di atas, Model Summary yang menghasilkan nilai Adjusted R Square sebesar 0.896, hal ini membuktikan bahwa terdapat sebesar $89.6 \%$ variabel Strategi Pemasaran (X1) dan variabel Pelayanan Umum (X2) secara bersama-sama berpengaruh dengan variabel Kepuasan Nasabah $(\mathrm{Y})$ dan sisanya sebesar $10.4 \%$ berpengaruh dengan faktor-faktor lain yang tidak diteliti dalam penelitian ini.

\section{E. KESIMPULAN}

Berdasarkan hasil uji analisis yan telah diperoleh berdasarkan tujuan maka dapat kesimpulan sebagai berikut : 1 . Pengaruh strategi pemasaran terhadap kepuasan nasabah, terbukti nilai thitung untuk Strategi Pemasaran (X1) sebesar 5.147, sedangkan nilai ttabel untuk $n=105$ sebesar 1.982. Jadi $5.147>1.982$ maka HO ditolak dan Ha diterima sehingga dapat dinyatakan maka Strategi Pemasaran (X1) berpengaruh terhadap Kepuasan Nasabah (Y) pada PT. Bank Danamon Tbk Kantor Cabang Tangerang Selatan. 2. Pengaruh pelayanan umum terhadap kepuasan nasabah, terbukti nilai thitung untuk Pelayanan Umum (X2) sebesar 6.091, sedangkan nilai ttabel untuk $n=105$ sebesar 1.982. Jadi $6.091>1.982$ maka HO ditolak dan Ha diterima sehingga dapat dinyatakan maka Pelayanan Umum (X2) berpengaruh terhadap Kepuasan Nasabah (Y) pada PT. Bank Danamon Tbk Kantor Cabang Tangerang Selatan. 3. Pengaruh strategi pemasaran dan pelayanan umum terhadap kepuasan nasabah, terbukti nilai Fhitung sebesar 449.727 sedangkan Ftabel $(\square 0,05)$ untuk $\mathrm{n}=105$ sebesar 2.69. Jadi Fhitung $>$ dari Ftabel $(\square 0,05)$ atau $449.727>2.69$, dengan tingkat signifikan sebesar 0,000 karena $0,000<0,05$ sehingga dapat dikatakan maka Strategi Pemasaran (X1) dan Pelayanan Umum (X2) secara bersama-sama berpengaruh terhadap Kepuasan Nasabah (Y). Sedangkan nilai Adjusted R Square sebesar 0.896, hal ini membuktikan bahwa terdapat sebesar $89.6 \%$ variabel Strategi Pemasaran (X1) dan variabel Pelayanan Umum (X2) secara bersama-sama berpengaruh dengan variabel Kepuasan Nasabah $(Y)$ dan sisanya sebesar $10.4 \%$ berpengaruh dengan faktor-faktor lain yang tidak diteliti dalam penelitian ini.

Dengan adanya hasil penelitian yang telah disimpulkan di atas, maka penulis memberikan saran sebagai berikut : 1. Untuk pihak PT. Bank Danamon Tbk Kantor Cabang Tangerang Selatan perlu tetap mempertahankan keempat program yang ada pada strategi pemasaran perusahaan dengan berupa melakukan program special promotion, Reward Bank Danamon, Jurnal Pemasaran Kompetitif, Vol. 03, No. 1 / Oktober 2019 
karena program-program ini sangat penting untuk meningkatkan jumlah nasabah. 2. PT. Bank Danamon Tbk Kantor Cabang Tangerang Selatan diharapkan agar memberikan pelayanan lebih baik lagi kepada nasabah hingga begitu dapat meyakinkan kepercayaan nasabah bahwa bank tidak pernah membuat kesalahan yang berakibat kesulitan atau merugikan nasabah dan pada akhirnya nasabah akan menilai baik pada pelayanan karyawan. 3. Diharapkan agar PT. Bank Danamon Tbk Kantor Cabang Tangerang Selatan memberikan kepuasan terhadap nasabah, karena kepuasan nasabah penting untuk diperhatikan dan kepuasan terbentuk dari pelayanan yang baik yang dilakukan pihak Bank Danamon, kepuasan nasabah harus dapat dipenuhi sehingga dapat menciptakan loyalitas.

\section{DAFTAR PUSTAKA}

Arief Muhammad. 2010. "Pengantar Metodologi penelitian untuk ilmu kesehatan". Surakarta: UPT Penerbitan dan Percetakan UNS.

Assauri, Sofjan. 2013. "Manajemen Pemasaran". Jakarta: Rajawali Pers.

Azwar, S. 2005. "Sikap Manusia, Teori dan Pengukurannya". Yogyakarta: Pustaka Pelajar.

Erlina, Sri Mulyani. 2007. "Metodologi Penelitian Bisnis, Untuk Akuntansi dan Manajemen". Medan: USU Press.

Ghozali, Imam. 2007. "Aplikasi Analisis Multivariate dengan (Program SPSS)". Semarang: Universitas Diponegoro.

Hasibuan, Malayu. 2012. "Manajemen Sumber Daya manusia". Jakarta: PT. Bumi Aksara.

Husein, Umar. 2011. "Metode Penelitian Untuk Skripsi dan Tesis Bisnis". Jakarta: PT. Raja Grafindo Persada.

Irma Fest, Nita Riski. 2016. "Analisis Swot Dalam Perencanaan Strategi Pemasaran Pada BMT Hasanah Jabung". Universitas Muhammadiyah Ponorogo.

Kotler, Philip dan Armstrong, Gary. 2012. "Principles of Marketing". New Jersey: Prentice Hall.

Lovelock, C, dan John Wirtz. 2011. "Pemasaran Jasa Perspektif". Jakarta: Erlangga.

Majid, .Suharto Abdul. 2011. "Customer Service dalam Bisnis Jasa Transfortasi". Jakarta: Rajawali Pers.

Nursalam. 2013. "Metodologi Penelitian Ilmu Keperawatan". Jakarta: Salemba Medika.

R. Terry, George dan Leslie W. Rue. 2010. "Dasar-Dasar Manajemen". Jakarta: Bumi Aksara.

Rangkuti, Freddy. 2014. "Analisis SWOT Teknik Membedah Kasus Bisnis". Jakarta: Gramedia Pustaka Utama.

Ratminto dan Atik Septi Winarsih. 2013. “Manajemen Pelayanan”. Yogyakarta: Pustaka Belajar.

. 2015. "Manajemen Pelayanan". Yogyakarata: Pusataka Pelajar.

Riduwan dan Sunarto. 2013. "Pengantar Statistika, Untuk Penelitian Pendidikan, Sosial, Ekonomi, Komunikasi, dan Bisnis". Bandung: Alfabeta.

Sedarmayanti. 2009. "Sumber Daya Manusia dan Produktivitas Kerja". Bandung: CV. Mandar Maju.

2010. "Manajemen Sumber Daya Manusia Reformasi Birokrasi dan Manajemen Pegawai Negeri Sipil". Bandung; PT Refka Aditama.

Sugiyono. 2011. "Metode Penelitian Kuantitatif, Kualitatif dan R\&D”. Bandung: Afabeta. 2012. "Metode Penelitian Kuantitatif Kualitatif dan R\&D". Bandung: Alfabeta. 2013. "Metode Penelitian Pendidikan Pendekatan Kuantitatif, Kualitatif, dan R\&D". Bandung: Alfabeta. 2014. "Metode Penelitian Pendidikan Pendekatan Kuantitatif, Kualitatif Dan

R\&D". Bandung: Alfabeta.

Sukmadinata. 2006. "Metode Penelitian Kualitatif". Bandung: Graha Aksara.

Tjiptono, Fandy. 2010. "Strategi Pemasaran". Yogyakarta: Andi Offset. 